Endocrinol. Japon. 1967, 14 (4) 320 326

\title{
ENDOCRINOLOGICAL STUDIES ON ENVIRONMENTAL AND PSYCHIATRIC MENSTRUAL DISORDERS
}

\author{
SEIICHI MATSUMOTO, Masao IGARACSI, Kodo TOHMA, \\ Hiroshi KUBO and NAOMI YOKOTA \\ Department of Obstetrics and Gynecology, School of Medicine, \\ Gunma University, Maebashi
}

\begin{abstract}
SYNOPSIS
Twenty six women showing acute psychogenic or environmental amenorrhea and twenty eight psychiatric female patients with amenorrhea were investigated with regard to serum LH bioassay and various urinary hormone assays. In the majority of those with acute environmental or psychogenic amenorrhea, a peculiar endocrinological pattern with low total gonadotrophin, low serum LH, high $170 \mathrm{HCS}$ and high $17 \mathrm{KS}$ was confirmed. In amenorrhea accompanied by endogenous psychosis, such as schizophrenia, the same endocrinological pattern was dominant. These results strongly suggest that the mechanism of the amenorrhea due to acute environmental change or psychiatric disorders is consistent with the shift theory of pituitary function proposed by Selye.
\end{abstract}

More than 20 years ago a type of amenorrhea induced by psychic trauma or environmental change was recognized (Klinefelter et al., 1943; Reifenstein, 1946). The pathogenesis of such emotional or hypothalamic amenorrhea has not yet been fully clarified. Moreover, the amenorrhea that may accompany mental disease as schizophrenia and epilepsy is still open to future investigation. The purpose of this paper is to attempt to find out if there is an endocrinological pattern characteristic of such environmental or psychogenic amenorrhea. A preliminary report has already appeared (Matsumoto et al., 1962a).

\section{MATERIALS AND METHODS}

Twenty six women whose amenorrhea followed an acute environmental change or psychic trauma were investigated (Table 1). All had had regular menstrual flows previously, with a sudden onset of amenorrhea after some acute crisis as a new job, a surgical operation or having been arrested for a crime.

Two other women, ages 24 and 25, were included who developed anovulatory cycles just after a new employment and acute exhaustion respectively. Twenty eight amenorrheic patients with coincident mental disease were also investigated, including twenty cases of schizophrenia, 1 case of manic depressive psychosis, 1 case of depression, 3 cases of neurosis and 3 cases of epilepsy.

Assay of urinary estrogen, gonadotrophin, $17 \mathrm{KS}$ and $17 \mathrm{OHCS},{ }^{*}$ and progesterone adminis-

Received for publication September 25, 1967.

* Urinary estrogen: Extracted by Nakayama-Hosoi's method and fluometrically determined by Akasu-Ohki's method. Urinary gonadotrophin: HCG augmented mouse uterine method by Igarashi and Hosaka. Urinary 17KS: Hydrolysis and extraction were performed by Robbie and Gibson's method and the determination by Zimmermann's reaction according to Callow's method. Urinary 17OHCS: Watanabe's and Takemoto's modification of Porter-Silber's method. 

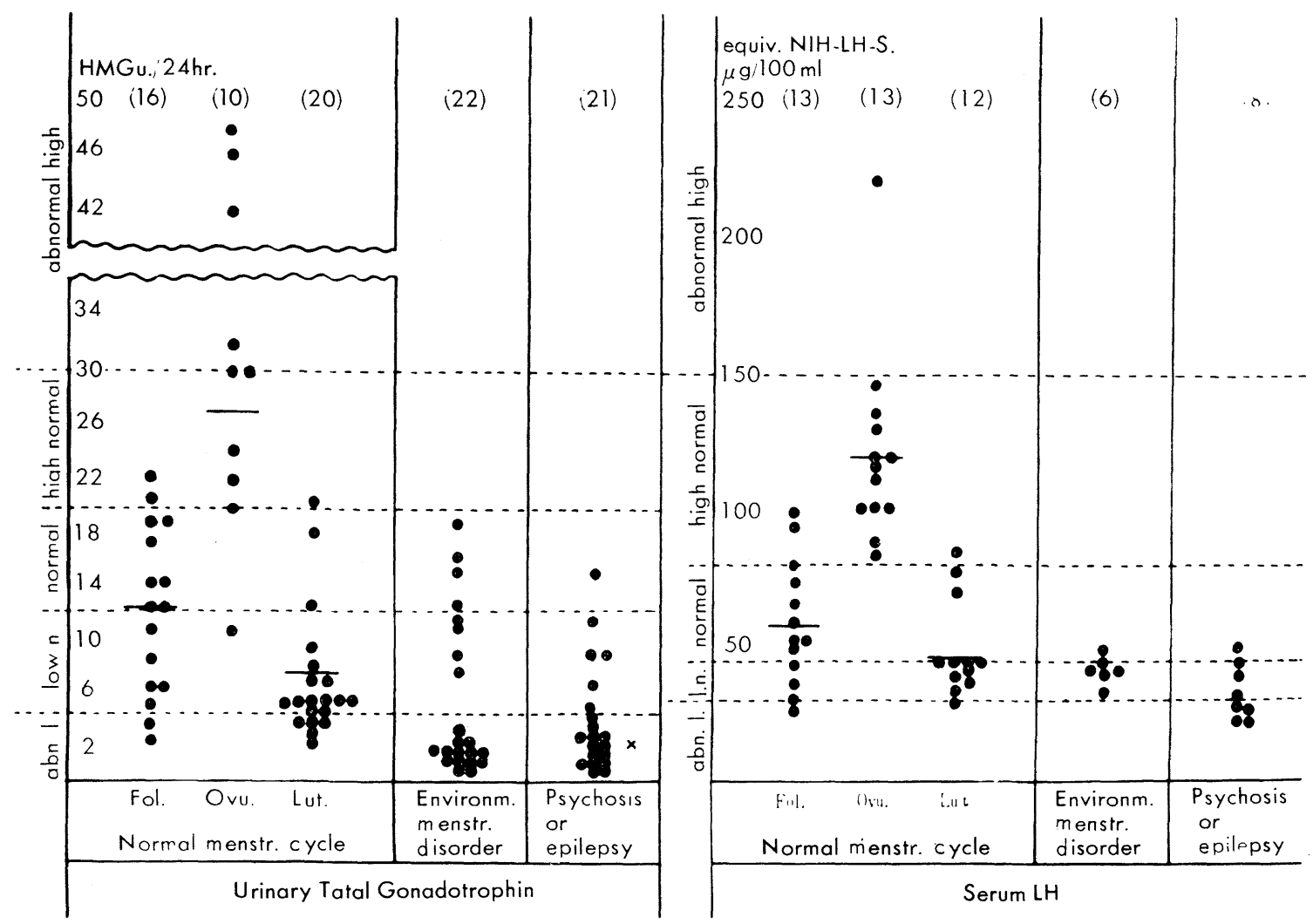

Fig. 1. Values of urinary total guiaciumuphin and serum LH in the cases of acute environmental menstrual disorders and the patients with amenorrhea associated with psychosis or epilepsy, compared with that of normal menstrual cycles. The number of cases is in parenthesis. $\times$ means case with epilepsy.

tration tests were performed in most cases, by the methods previously reported (Matsumoto et al., 1962). Serum LH levels were assayed by a modified Parlow's ovarian assorbic acid depletion test (OAAD) (Yokota et al., 1965). The normal range for these assay methods were determined and divided in 3 parts; high normal, normal and low normal, as shown in Figures 1 and 2 , on the basis of assays on women with normal menstrual cycles.

\section{RESULTS}

The values of urinary total gonadotrophin and serum LH in the cases of acute environmental menstrual disorders are summarized in Figure 1 and the values of urinary $17 \mathrm{KS}$ and $17 \mathrm{OHCS}$ in Figure 2. It can be seen there that the majority of those with acute environmental amenorrhea or anovulatory cycles showed a characteristic pattern of concomitant abnormal low or low normal urinary gonadotrophin levels and abnormal high or high normal urinary $17 \mathrm{KS}$ and 17 OHCS. The values of urinary estrogen are abnormal low in 5 cases, low normal in 9 cases and normal in 5 cases, as shown in Figure 3. As for relation between urinary gonadotrophin and estrogen, the latter was normal in 11 of 13 cases with low gonadotrophin level (Table 2).

There was only one case with normal gonadotrophin and low estrogen, which Reifenstein has suggested as characteristic of hypothalamic amenorrhea. As for the relations between urinary gonadotrophin, 


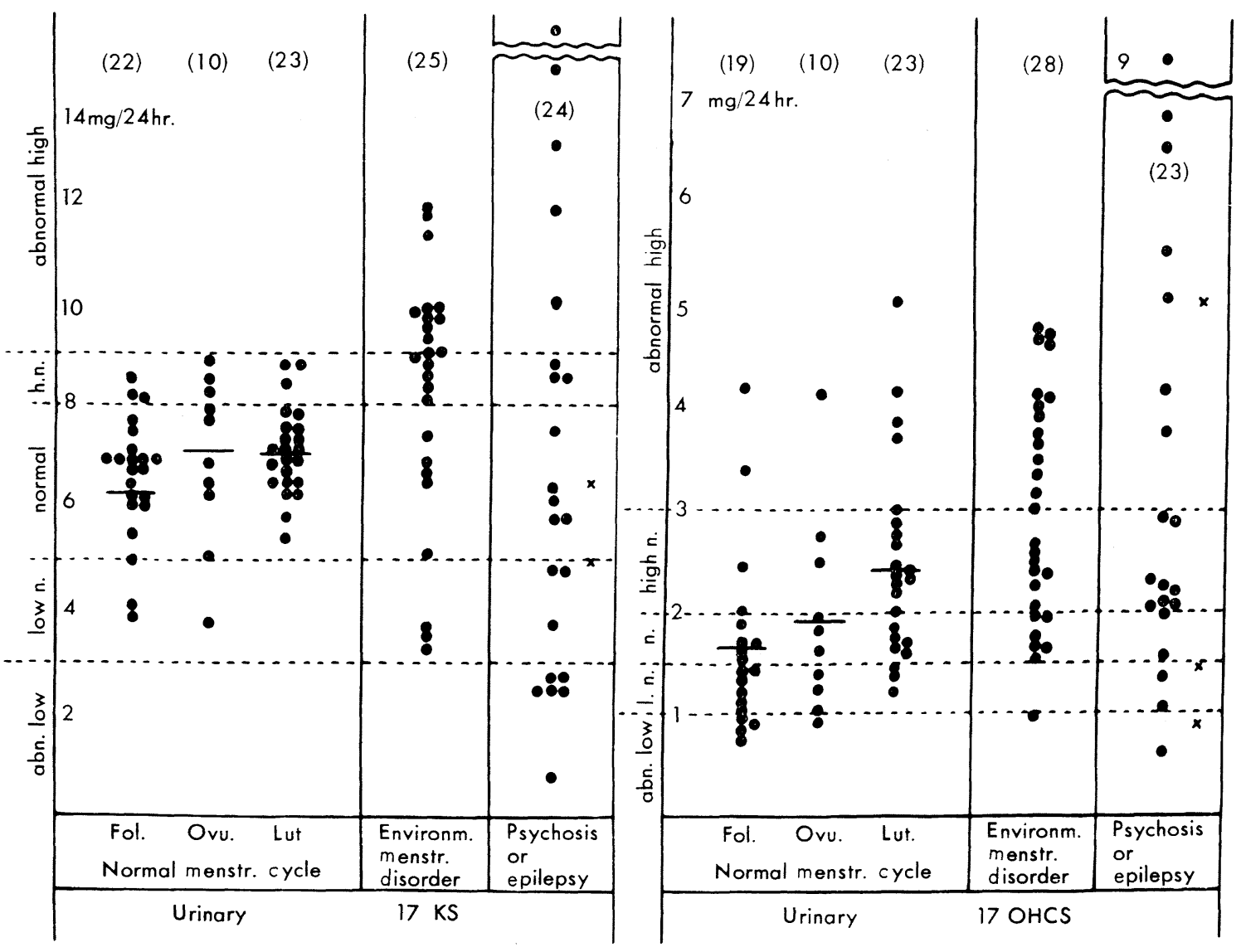

Fig. 2. Values of urinary $17 \mathrm{KS}$ and $17 \mathrm{OHCS}$ in the cases of acute environmental menstrual disorders and the patients with amenorrhea associated with psychosis or epilepsy, compared with that of normal menstrual cycles. The number of cases is in parenthesis. $\times$ means case with epilepsy.

$17 \mathrm{OHCS}$ and $17 \mathrm{KS}$, those with low gonadotrophin and high $17 \mathrm{OHCS}$ and $17 \mathrm{KS}$ constituted the majority (Table 3 ) as previously reported.

Serum LH of 6 patients with environmental amenorrhea was lower than in controls, while within normal range (Fig. 1). According to a classification on the bases of endocrinological findings, reported by Matsumoto et al. (1962), type III (shift type), characterized by low or normal gonadotrophin and high 17OHCS and/or $17 \mathrm{KS}$, accounted for the largest number of all.

Results of various endocrinological assays

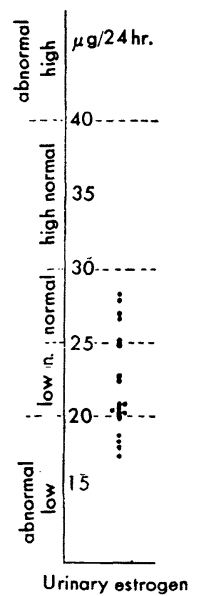

Fig. 3. Values of urinary estrogen in the cases of acute environmental menstrual disorders. 
Table 1 Cases with ameuorrhea followed an acute environmental change or psychic trauma

\begin{tabular}{|c|c|c|c|c|c|c|c|c|c|c|c|c|c|c|}
\hline \multirow{3}{*}{$\begin{array}{l}\text { Acute } \\
\text { environ- } \\
\text { mental } \\
\text { change }\end{array}$} & \multirow{3}{*}{$\begin{array}{l}\text { No. } \\
\text { of } \\
\text { cases }\end{array}$} & \multirow{3}{*}{ Age } & \multirow{2}{*}{\multicolumn{5}{|c|}{$\begin{array}{l}\text { Number of cases } \\
\text { by duration of } \\
\text { Amenorrhea (Month) }\end{array}$}} & \multirow{2}{*}{\multicolumn{3}{|c|}{$\begin{array}{l}\text { No. of cases by } \\
\text { gestagen adminis- } \\
\text { tration test }\end{array}$}} & \multicolumn{4}{|c|}{ No. of cases by prognosis } \\
\hline & & & & & & & & & & & \multirow{2}{*}{$\begin{array}{l}\text { Sponta } \\
\text { neous } \\
\text { recovery }\end{array}$} & \multirow{2}{*}{$\begin{array}{l}\text { Recovery } \\
\text { after } \\
\text { treatment }\end{array}$} & \multirow{2}{*}{$\begin{array}{l}\text { Uneffe- } \\
\text { ctive }\end{array}$} & \multirow{2}{*}{$\begin{array}{l}\text { Under } \\
\text { obser- } \\
\text { vation }\end{array}$} \\
\hline & & & $2-3$ & $4-6$ & $7-9$ & $10-14$ & $\begin{array}{l}\text { Uu- } \\
\text { clear }\end{array}$ & + & - & $\begin{array}{c}\text { Not } \\
\text { tested }\end{array}$ & & & & \\
\hline Detention & 16 & $16-20$ & 5 & 6 & 3 & 2 & 0 & 9 & 5 & 2 & 7 & 3 & 4 & 2 \\
\hline Employment & 3 & $15-20$ & 1 & 0 & 2 & 0 & 0 & 1 & 2 & 0 & 1 & 2 & 0 & 0 \\
\hline $\begin{array}{l}\text { Admission } \\
\text { to hospital }\end{array}$ & 3 & $22-25$ & 2 & 1 & 0 & 0 & 0 & 3 & 0 & 0 & 3 & 0 & 0 & 0 \\
\hline Operation & 2 & 20,34 & 1 & 0 & 0 & 0 & 1 & 1 & 1 & 0 & 1 & 0 & 1 & 0 \\
\hline $\begin{array}{l}\text { Change of } \\
\text { environment }\end{array}$ & 2 & 20,25 & 1 & 0 & 1 & 0 & 0 & 1 & 0 & 1 & 0 & 1 & 0 & 1 \\
\hline Total & 26 & & 10 & 7 & 6 & 2 & 1 & 15 & 8 & 3 & 12 & 6 & 5 & 3 \\
\hline
\end{tabular}

Table 2. Relationship between urinary gonadotrophin and estrogen levels in the cases $\mathrm{with}$ environmental menstrual disorder

\begin{tabular}{cclr}
\hline Gonadotrophin level & \multicolumn{2}{l}{ Estrogen level } \\
\hline Normal & 7 & Normal & 6 \\
& & Low & 1 \\
\hline Low & 13 & Normal & 11 \\
& & Low & 2 \\
\hline
\end{tabular}

performed on patients with amenorrhea associated with psychosis or epilepsy were as shown in Figures 1 and 2. The greatest number of these patients showed low gonadotrophin and high $17 \mathrm{OHCS}$. Four cases out of 8 showed very low serum $\mathrm{LH}$ and the other 3 cases showed low values but within normal range. These patterns are just the same as in the above mentioned environmental disorders.

The relationship between urinary gonado- trophin and $17 \mathrm{OHCS}$ or $17 \mathrm{KS}$ in the patients with endogenous psychosis or neurosis is shown in Table 4.

From these results it is suggested that the amenorrhea complicated with endogenous psychosis would have the same etiological mechanism as environmental amenorrhea.

\section{DISCUSSION}

Amenorrhea which is considered to result from intereference with the hypothalamicpituitary pathway that blocks release of $\mathrm{LH}$, owing to evident or occult psychic trauma, is designated by Klinefelter et al. (1943) as hypothalamic amenorrhea.

According to Reifenstein (1946), diagnosis of psychogenic or hypothalamic amenorrhea can be made by the story of psychic trauma immediately before the commencement of

Table 3. Relationship between urinary gonadotrophin and $17 \mathrm{KS}$, or

$170 H C S$ levels in the cases with environmental menstrual disorder

\begin{tabular}{|c|c|c|c|c|c|c|c|c|}
\hline \multirow[b]{2}{*}{$\begin{array}{c}\text { Gonadotrophin } \\
\text { levels }\end{array}$} & \multicolumn{4}{|c|}{$17 \mathrm{KS}$} & \multicolumn{4}{|c|}{$17 \mathrm{OHCS}$} \\
\hline & $\underset{\text { high }}{\text { Abnormal }}$ & $\begin{array}{l}\text { High } \\
\text { normal }\end{array}$ & Normal & $\begin{array}{c}\text { Low } \\
\text { normal } \\
\text { and } \\
\text { abnormal } \\
\text { low }\end{array}$ & $\begin{array}{l}\text { Abnormal } \\
\text { high }\end{array}$ & $\begin{array}{c}\text { High } \\
\text { normal }\end{array}$ & Normal & $\begin{array}{c}\text { Low } \\
\text { normal } \\
\text { and } \\
\text { abnormal } \\
\text { low }\end{array}$ \\
\hline Abnormal high & 0 & 0 & 0 & 0 & 0 & 0 & 0 & 0 \\
\hline Normal & 3 & 2 & 0 & 0 & 3 & 1 & 1 & 0 \\
\hline Low normal & 1 & 2 & 0 & 0 & 2 & 0 & 1 & 0 \\
\hline Abnormal low & 7 & 2 & 4 & 0 & 6 & 5 & 1 & 1 \\
\hline
\end{tabular}


Table 4. Relationship between urinary gonadotrophin and $17 \mathrm{KS}$ or $17 \mathrm{OHCS}$ levels in the amenorrheal patients associated with endogenous psychosis or neurosis

\begin{tabular}{lcccccccccc}
\hline \hline \multirow{2}{*}{$\begin{array}{c}\text { Gonadotrophin } \\
\text { levels }\end{array}$} & $\begin{array}{c}\text { Ab- } \\
\text { normal } \\
\text { high }\end{array}$ & $\begin{array}{c}\text { High } \\
\text { normal }\end{array}$ & Normal & $\begin{array}{c}\text { Normal } \\
\text { low }\end{array}$ & $\begin{array}{c}\text { Ab- } \\
\text { normal } \\
\text { low }\end{array}$ & $\begin{array}{c}\text { Ab- } \\
\text { normal } \\
\text { high }\end{array}$ & $\begin{array}{c}\text { High } \\
\text { normal }\end{array}$ & $\begin{array}{c}\text { Normal } \\
\text { Normal } \\
\text { low }\end{array}$ & $\begin{array}{c}\text { Ab- } \\
\text { normal } \\
\text { low }\end{array}$ \\
\hline $\begin{array}{c}\text { Abnormal high } \\
\text { high normal }\end{array}$ & 0 & 0 & 0 & 0 & 0 & 0 & 0 & 0 & 0 & 0 \\
Normal & 0 & 0 & 0 & 0 & 0 & 0 & 1 & 0 & 0 & 0 \\
Low normal & 1 & 0 & 1 & 1 & 2 & 0 & 1 & 0 & 1 & 1 \\
Abnormal low & 5 & 0 & 2 & 2 & 3 & 5 & 5 & 1 & 1 & 1 \\
\hline
\end{tabular}

amenorrhea with the finding of normal FSH excretion, deficient estrogen activity, and ability of the endometrium to respond to estrogen-withdrawal bleeding. This was supported by Sturgis (1945) and Greenhill (1953), and accepted by many workers.

On the other hand, Goldzieher and Goldzieher (1952) showed the possible occurence of rapid destruction or abnormal progesterone metabolism in some cases of psychogenic amenorrhea produced by psychic impulses or violent emotion. Joel et al. (1956) reported a case of amenorrhea, which could be explained to have resulted from unresponsiveness of the target organ to the stimulation of ovarian hormones, and Netter et al. (1957) observed high FSH excretion in all the ten cases in which amenorrhea was produced by severe psychic shock. Polishuk et al. (1960) reported on 3 cases of psychogenic amenorrhea in which estrogenic activity was deficient by vaginal smear, uterine bleeding was not induced by prolonged administration of estrogen, but in all of them menstruation returned spontaneously following various psychic stimuli; and he indicated the possibility that some other mechanism than suppression of LH would be involved in the development of psychogenic amenorrhea.

Staemmler (1961) reported that hypothalamic amenorrhea responded to gonadotrophin (PMS and HCG) in $72 \%$ of cases, and Rakoff (1962) who classified 38 cases of psychogenic menstrual disorders into 6 endocrinological types, reported that the largest number had simple hypogonadotrophism. Lloyed (1960) found that psychic trauma or considerable emotional hyperactivity sometimes induced amenorrher without any evident organic diseases, which he designated as "idiopathic amenorrhea"; and he reported that, although laboratory findings from these patients were varying, urinary gonadotrophin was generally lowered when the amenorrhea persisted, but infrequently elevated immediately after emotional stress, assumedly because of deficient release or imbalance of one or the other gonadotrophin. As to psychological and psychoanalytical findings and personalities of patients with psychogenic amenorrhea, there were reports by Piotrowski (1962), Loftus (1962), Geijerstam (1960) and Sturgis (1962).

Studies on assays of blood or urinary gonadotrophin in psychogenic or environmental amenorrhea were few and limited. Our results demonstrating low serum LH levels in environmental amenorrhea are the first that have been reported on blood gonadotrophin levels in amenorrhea patients. These results appear to coincide with the report of McArthur et al. (1958) who recognized a low ICSH (LH) excretion from 2 cases of psychogenic amenorrhea and to support the aforementioned Klinefelter-Reifenstein's hypothesis. Urinary total gonadotrophin levels, assayed by the mouse uterine weight method, were also in abnormally low or low normal range. Sase et al. (1957) as well noted a decrease in urinary gonadotrophin and estrogen and an increase in urinary corticosteroids in detention amenorrhea. These results are consistent with Klinefelter-Reifenstein's 
hypothesis. Tietze (1952) referred to amenorrhea which results from an adverse environment or acute debility from systemic disease as "Notstandamenorrhea" (emergency amenorrhea), and he consideres it as a protective reaction of the body to its emergency. According to Elert (1952), this amenorrhea develops because the hypothalamus reacts against emergency by stimulating the pituitary to release more $\mathrm{ACTH}$ than gonadotrophin. Our results clearly demonstrate that both the increase of ACTH release and the decrease of FSH and LH release from the pituitary occur concomitantly in acute psychogenic or environmental amenorrhea. These patterns are the first demonstration of the hypothesis on "shift phenomenon" of the pituitary function suggested by Selye (1939) and Elert (1952). Recently, Igarashi (1966) recognized that no significant difference was observed in plasma and pituitary FSH levels, but plasma LH level apparently decreased as the experimental rats were affected by cold stress.

In the field of psychology, Board et al. (1957) observed in psychologically depressed patients, the most retarded and least expressive ones had highest levels of $17 \mathrm{OHCS}$ excretion and Persky et al. (1958) reported that when men were exposed to unfamiliar, novel situation containing some uncertainty and ambiguity, release of adrenocortical hormones was accelerated. Suwa et al. (1962) demonstrated that the functions involved in urinary 17OHCS, circulating eosinophil count and uropepsin were synchronous with changes in emotional states in psychoneurotics and that schizophrenics revealed adrenocortical hyperactivity during psychic aggravation. All these indicate an important role played by the pituitary-adrenal function in acute psychic trauma and psychopathies.

Menstrual disorders in psychotic patients have been also observed. According to Rey et al. (1957) the main pattern of amenorrhea accompanied by psychosis is a kind of hypopituitarism in which estrogen and gonadotrophin levels are low and $17 \mathrm{KS}$ levels tend to be normal or low within the normal range.
Hatotani (1959) reported that among the patients with menstrual disorders accompanies by either acute or periodic psychosis, there were cases presenting gonadal hypofunction and relative adrenocortical hyperfunction. Recently Ito (1964) reported that the deviation of urinary total gonadotrophin levels in mental diseases such as schizophrenic and manic-depressive psychosis was induced by the derangement of the endocrine equilibrium produced by emotional change, and the urinary gonadotrophin levels showed wide variation, but were abnormally or comparatively low when the emotional state of the patient is remarkably disturbed. Our present results, in agreement with those of Hatotani and Ito, showed high urinary $17 \mathrm{OHCS}$ and low gonadotrophin and estrogen levels in the majority of psychotics. It is noteworthy that these patterns in psychosis are the same as in psychogenic or environmental amenorrhea. From these results it is suggested that the pathogenesis of amenorrhea accompanied by various psychosis, similar to that in psychogenic or environmental amenorrhea, can be explained by a "shift phenomenon" of anterior pituitary function.

\section{ACKNOWLEDGEMENT}

The authors would like to express their gratitude to Dr. Somers H. Sturgis for his helpful suggestions and his revision of the English manuscript.

\section{REFERENCES}

Board, F., R. Wadeson, and H. Persky (1957). A. M. A. Arch. Neurol. and Psychiat. 78, 612. Elert, R. (1952). Geburtsh. u. Frauenhk. 12, 193. Geijerstam, G. A. (1960). Acta Obstet. Gynec. Scand. 39, 346.

Goldzieher, M. A. and J. W. Goldzieher (1952).

J. Clin. Endocrinol. 12, 42.

Greenhill, J. P. (1953). Gynec. prat. 4, 431.

Hatotani, T. (1959). Seishin-Igaku 1, 377. (in Japanese)

Igarashi, M. (1967). Studies on Secretion of 
Pituitary Gonadotrophins, An Invited Lecture on a Pending Question, Presented at the 19th Annual Meeting of the Japanese Obstetrical and Gynecological Society, Nagoya, Japan. (in Japanese)

Ito, K. (1964). Psychiatria et Neurologia Japonica 66, 178.

Joel, C. A. and M. Lancet (1956). J. Clin. Endocrinol. 16, 909.

Klinefelter, H. F., F. Albright and G. C. Griswold (1943). Ibid. 3, 529.

Lloyd, C. W. (1960). Clin. Obstet. and Gynec. 3, 971.

Loftus, T. A. (1962). Fertil. Steril. 13, 20.

Matsumoto, S. et al. (1962a). J. Jap. Obstet. and Gynec. Soc. 9, 161.

Matsumoto, S. et al. (1962b). Gunma J. Med. Sci. 11, 95.

McArthur, J. W., F. M. Ingersoll and J. Worcester (1958). J. Clin. Endocrinol. 18, 1202.

Netter, A. et al. (1957). Ann. Endocrinol. 18, 1014.

Persky, H., et al. (1958). A. M. A. Arch. Neurol. and Psychiat. 79, 434.

Pitowski, Z. A. (1962). Fertil. Steril. 13, 11.
Polishuk, W. Z., E. Paldi and H. Hazan (1960). Int. J. Fertil. 5, 139.

Rakoff, A. E. (1962). Fertil. Steril. 13, 1.

Reifenstein, E. C. (1946). Med. Clin. North America 304, 1103.

Rey, J. H., Nicholson-Bailey, U. and A. Trappl (1957). Brit. Med. J. 2. 843.

Sase, T., et al. (1957). Kyosei-Igaku 6, Spec. Issue 77. (in Japanese)

Selye, H. (1939). Endocrinology 25, 615.

Staemmler, H.-J. (1961). Arch. Gynäk. 195, 468.

Sturgis, S. H. Amenorrhea: Classification and Diagnostic Test. in Prog. in Gynecol. Grunne and Stratton, New York p. 106 (1946).

Sturgis, S. H. The Gynecological Patient, Grunne and Stratton, New York. (1962).

Suwa, N., et al. (1962). J. of Nervous and Mental Disease 134, 268.

Tietze, K. (1962). Die Weibliche Zyklus und seine Störungen; Seitz-Amreich, Biologie u. Pathologie d. Weibes, Bd. 2, 491, Urban and Schwarzenberg, Wien.

Yokota, N., M. Igarashi, and S. Matsumoto (1965). Endocrinol. Japon. 12, 83. 